\title{
Analysis Screening Information System and Stunting Early Detection
}

\author{
Muhammad Rizal Permadi ${ }^{1 *}$, Muhammad Iqbal ${ }^{2}$, Huda Oktafa ${ }^{3}$ \\ ${ }^{1,2,3}$ Department of Clinical Nutrition, Politeknik Negeri Jember, Indonesia \\ *Corresponding author. E-mail: rizalpermadi@ polije.ac.id
}

\begin{abstract}
Stunting is a growth failure in children under five, characterized by height for age less than -2 standard deviations. According to Basic Health Research (RISKESDAS) in 2018 Indonesia is one of the countries with a very high incidence of stunting, namely $30.8 \%$. This problem is a system for reporting and tracking stunting children under five is still using manuals, Integrated Service Post cadres after taking height measurements and then entering them into records and reporting them periodically every month, health workers who will recap the results. The research aimed to develop and evaluate features of screening and early detection of stunting in Kick stunting websites that can be applied to primary health care. This type of research is Research and Development ADDIE model. After the implementation step, the evaluation will be continued by asking for expert opinions regarding the Kick stunting website. Validation is done by media experts and material experts given questionnaires. Descriptive statistics did data analysis. Based on the need analysis, there were 6 functions needed in developing this kickstunting website. The evaluation result kickstunting website is acceptable, as a simple, practical app with well-arranged app structure, good display, and easy to use. and ready used by nutritionists, Integrated Service Post cadres, and toddler mothers.
\end{abstract}

Keywords: Website, Stunting, Screening, Early Detection

\section{INTRODUCTION}

Stunting is growth failure of children under five characterized by height for age (TB/U) less than -2 standard deviations from the median growth standard for children set by the World Health Organization[1]. Indonesia is a country with a high prevalence of stunting, which is $30.8 \%$ [2]. The impact of stunting on children can be short-term and long-term. In addition, stunting can increase morbidity and mortality, poor child development and learning capacity, increased risk of infection and non-communicable diseases in adulthood, and decreased productivity and economic capacity [3].

It is estimated that stunting can cause economic losses to the country by 2-3 percent of the Gross Domestic Product (GDP) per year. If our country's GDP was IDR 13,000 trillion in 2017, it is estimated that the potential loss due to stunting can reach IDR 300 trillion per year [4]. Reducing stunting is the first of the six goals in the 2025 Global Nutrition Targets [5] and the main indicator in the Sustainable Development Goals of Zero Hunger or SDG's [6]. In addition, stunting is a priority for the Indonesian government as stated in the National Priority Program [4]. The government has made various efforts to reduce the stunting problem and various policies and regulations as well as through a number of interventions [7]. However, the prevalence is still high above $20 \%$, other creative actions are needed so that this stunting case can be quickly resolved.

The solution to this problem is to use an information technology-based website, very appropriate in the era of the covid-19 pandemic to maintain distance and change face-to-face to online [8]. Making a website to solve health problems, has proven to be applicable and can be applied in the community[9]. The kick stunting website that will be designed will prioritize the standard of height for age $(\mathrm{TB} / \mathrm{U})$ which is the main indicator in establishing a stunting diagnosis. If the results of the calculation of nutritional status do not meet the requirements, the system will immediately send a notification to the health officer in the work area. The kickstunting website will make mothers of toddlers proactively participate in reporting the condition of their children. The study aims to develop and evaluate a website for screening and early detection of stunting.

\section{METHOD}

This research is a development research known as Research \& Development (R\&D). Development research is a research method used to create a product and test its effectiveness [10]. This research used the 
ADDIE development model. This development model consists of five steps namely, analysis, design, development, implementation, and evaluation. This model was arranged in sequence to solve learning problems related to learning media corresponding to the respondent's needs and characteristics [11]. This model has understandable steps to develop a kick stunting website. After the implementation step, the evaluation will be continued by asking for expert opinions regarding the kickstunting website. Validated by media experts and material experts have given questionnaires. Questionnaires asking how much they agree with various aspects such as simplicity, practicability, conformity to expectations, time-saving, effectiveness, conformity to setting structure need, display, and convenience of the feature kick stunting website. The data were analyzed employing descriptive statistics.

\section{RESULTS AND DISCUSSION}

\subsection{Analyze}

In this stage, analyze the need for a kick stunting website by manual for assessing the nutritional status of children, the method commonly used by nutritionists in general. This evaluation focuses on finding out the nutritional status in the existing manuals would be illustrated and adjusted into a more responsive and easy-to-use website form. That was very vital in the product development website.

Assessment of the nutritional status of stunting children based on body length according to age (PB/U), can be categorized into tall, normal, short and very short. Determination of short children based on a standard deviation that has been standardized. The nutritional status of children according to $\mathrm{PB} / \mathrm{U}$ is done by manually matching the child's height with the standard deviation. analysis of the needs of what features are on the kick stunting website as shown in table 1 .

Table 1. Analysis of function needs in Kickstunting website

\begin{tabular}{|c|l|l|}
\hline No & \multicolumn{1}{|c|}{ Need Urgency } & \multicolumn{1}{|c|}{$\begin{array}{c}\text { Functional } \\
\text { Component }\end{array}$} \\
\hline 1 & $\begin{array}{l}\text { Name caders dan } \\
\text { nutrisionist }\end{array}$ & Login function \\
\hline 2 & $\begin{array}{l}\text { Calculating nutritional } \\
\text { status }\end{array}$ & $\begin{array}{l}\text { Nutritional status } \\
\text { calculator }\end{array}$ \\
\hline 3 & $\begin{array}{l}\text { Determining the home } \\
\text { area for cadres, children } \\
\text { and nutritionists }\end{array}$ & Map area \\
\hline 4 & $\begin{array}{l}\text { Child growth } \\
\text { monitoring }\end{array}$ & Growth graph \\
\hline 5 & $\begin{array}{l}\text { Input child name, age, } \\
\text { gender, height, weight }\end{array}$ & $\begin{array}{l}\text { Input child } \\
\text { profile }\end{array}$ \\
\hline 6 & $\begin{array}{l}\text { Delivery stunting } \\
\text { notification }\end{array}$ & Notification \\
\hline
\end{tabular}

\subsection{Design}

The product is designed starting from the appearance to the product's material based on the analysis stage and literature study to determine the material used. The media design produced at this stage is still conceptual and will underlie the further development process. The design of this kick stunting website feature includes the design of the main features which include the login function, nutritional status calculator and $\mathrm{z}$ score, graphs, regions, notifications, etc.

\subsection{Development}

This stage contains a backend or coding process to realize the feature functions designed. Furthermore, a thorough validation of the website is carried out. If there are improvements, the website will be revised until the results are good. Solutions for these errors are sought from the backend side so that they can function normally, this is because they involve various functions that must exist and there should be no errors. Some improvements can be seen in table 2 .

Table 2. The differences before and after repair

\begin{tabular}{|c|c|c|}
\hline No & Problem & After Revision \\
\hline 1 & $\begin{array}{l}\text { The selection of } \\
\text { the Kick Stunting } \\
\text { Icon is not } \\
\text { representative of } \\
\text { the function }\end{array}$ & $\begin{array}{l}\text { Changing the shape of the } \\
\text { stunting kick icon with a } \\
\text { human symbol display }\end{array}$ \\
\hline 2 & $\begin{array}{l}\text { The results of the } \\
\text { calculation of the } \\
\text { nutritional status } \\
\text { of } \\
\text { undernourished }\end{array}$ & $\begin{array}{l}\text { Accurate calculation } \\
\text { according to standard }\end{array}$ \\
\hline 3 & $\begin{array}{l}\text { Region icon is not } \\
\text { depicting }\end{array}$ & $\begin{array}{l}\text { Replaced according to the } \\
\text { regional icon }\end{array}$ \\
\hline 4 & $\begin{array}{l}\text { Graphics don't } \\
\text { look clear }\end{array}$ & $\begin{array}{l}\text { Change to a more } \\
\text { contrasting color }\end{array}$ \\
\hline 5 & $\begin{array}{l}\text { The login } \\
\text { function } \\
\text { be uned }\end{array}$ & $\begin{array}{l}\text { Repaired so that it can run } \\
\text { well }\end{array}$ \\
\hline 6 & $\begin{array}{l}\text { The default date } \\
\text { is still random }\end{array}$ & Default date today \\
\hline 7 & $\begin{array}{l}\text { Notification not } \\
\text { sent }\end{array}$ & Notif \\
\hline
\end{tabular}

\subsection{Implementation}

The application design has been developed and is final, so the next stage is implementation and testing in real situations, namely nutritionists who work in health centers, cadres and mothers of toddlers. The results of the final application are shown in the pictures below. 


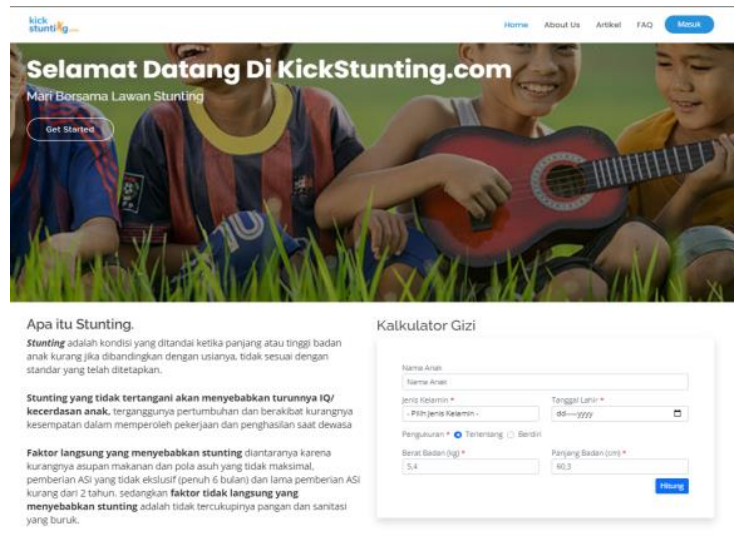

Figure 1 Homepage view final kickstunting website ready to implement.

The implementing of the required features on the kickstunting website application is by the design and development. These features will help facilitate use by Nutritionists, mothers of toddlers and cadres

\subsection{Evaluation}

Evaluation is the process to see if the feature developed conforms to the initial expectation or not. Evaluation is the last step in the ADDIE learning system design model. Evaluation is a process to evaluate the media developed [12]. In this step, the final product was generated and has been tested. It was expected that the final product can be truly worthy of use. The next research stage is to evaluate the website that has been created. The evaluation involved material experts and media experts. Evaluation is done quantitatively and qualitatively. Material experts and media experts can provide input regarding things that need to be improved for the perfection of the kick stunting website.

Evaluation of the material expert by the Nutritionist, agree and strongly agree if the kick stunting website is simple, as expected, saves time, is effectively used, meets the needs, the arrangement of the application settings is good, the application display is good and easy to use. Media validators like all aspects, but one aspect that the kickstunting website likes the most is that there is a nutrition calculator, which can calculate the nutritional status of children and display it in graphic form. Suggestions from the material validator are to add the latest articles and research results related to stunting. So that it can be a reference for cadres and health workers to solve the stunting problem

The evaluation from media experts gave four points, namely agreeing that the stunting website is simple, as expected, saves time, is effectively used, according to needs, the arrangement of application settings is good and easy to use. While disagree on the appearance of the application is good
This is one of the obstacles in a web-based app. There were 7 reasons for this slow loading [13] namely:

1. Bandwidth use failed to optimize

2. Dense network traffic

3. Coding error

4. Slow server

5. Specific HTML Title Tags

6. Network connection and DNS issue

The preferred aspect is that the website dynamics are good and the features are quite complete. The suggestion from the media validator is that in the future the kickstunting website can be used by the public to provide information related to stunting to reduce stunting rates. Another aspect that needs attention is data entry by the mother. Because the data related to stunting will be sent to cadres who work in the local area. So it is necessary to be careful in filling in the residential address.

\subsection{Discussion}

The kick stunting application can be used easily by parents of toddlers, posyandu cadres and health workers, by entering the toddler's height and age. This application will send notifications of the results of the nutritional status of children under five through a short massage service (sms), notifications via applications and user emails regarding the results of nutritional status so that if children under five are indicated to be stunted, it will be immediately known.

Kickstunting is so helpful for program implementers related to stunting in the field. This application collaborates participation between puskesmas, posyandu cadres and parents of toddlers. but there are some weaknesses of this research is the application can not be applied to those who do not have a smartphone. Apart from that, the internet network is one of the vital things for the use of this kickstunting application without which the application cannot run.

\section{CONCLUSION}

Based on the needs analysis, six functions are needed on the kickstunting website, namely the name of cadres and nutritionists, calculating nutritional status, determining the area of the house for children under five, cadres and nutritionists. Monitor growth, input the child's name, age, gender, height, weight and send notifications if the child is stunted. Meanwhile, there are several features that are experiencing problems but have been able to be overcome, namely the selection of kick stunting icons, calculation results of nutritional status, regional icons, graphics, log in functions, date settings and notifications not being sent. The results of the evaluation by material experts and media experts that the kick stunting website can be well received, as a simple, practical app with well- 
arranged app structure, good display, and easy to use. Kick stunting website looks perfect and can be used by nutritionists, integrated service post cadres and mothers of toddlers. Kickstunting is so helpful for program implementers related to stunting in the field. This application collaborates participation between puskesmas, posyandu cadres and parents of toddlers.

\section{ACKNOWLEDGMENTS}

This work was supported by Politeknik Negeri Jember through The Institute's Competitive Granted Fund (PNBP).

\section{AUTHORS' CONTRIBUTION}

MRP and MI participated in the design of the study. HO participated analyzed and interpreting the data. MRP drafted the paper and MI and HO critically revised important content. All authors read and approved the final manuscript

\section{REFERENCES}

[1] World Health Organization, The WHO Child Growth Standards, 2021. Accessed November 5 ,2021

http://www.who.int/childgrowth/standards/en/

[2] Kementerian Kesehatan RI. Riset Kesehatan Dasar (Riskesdas), 2018. Accessed $\begin{array}{lll}\text { November } & 8 & 2021\end{array}$ https://kesmas.kemkes.go.id/assets/upload/dir_ 519d41d8cd98f00/files/Hasil-riskesdas2018_1274.pdf

[3] C. P. Stewart, L. Iannotti, K. G. Dewey, K. F. Michaelsen, A. W. Onyango, Contextualising complementary feeding in a broader framework for stunting prevention. Elsevier, Amsterdam, 2013. pp. 27-45. DOI: https://doi.org/10.1111/mcn.12088

[4] Bappenas. Penurunan Prevalensi Stunting Proyek Priorotas Nasional, Bappenas 2020. Accessed October 8,2021

https://www.bappenas.go.id/files/1415/3309/1 396/Siaran_Pers -

Penurunan_Prevalensi_Stunting_Proyek_Prio ritas_Nasional.pdf

[5] Worl Health Organization (Ed.). Maternal, Infant And Young Child Nutrition. (WHO, Ed.). Geneva, Switzerland: The sixty - fifth world health assembly WHA65.6, 2012. Accessed November 12,2021

https://apps.who.int/gb/ebwha/pdf_files/WHA 65-REC1/A65_REC1-en.pdf

[6] United Nations, Department of Economic and Social Affairs. Goal 2: End hunger, achieve food security and improved nutrition and promote sustainable agriculture (sustainable development knowledge platform), 2016. Accessed November 15 ,2021https://sdgs.un.org/goals/goal2

[7] L. S. Nisa, Kebijakan Penanggulangan Stunting Di Indonesia. Jurnal Kebijakan Pembangunan, Balitbangda Kalsel, Banjarmasin, 2018, pp.173-179. Accessed November 18 ,2021, https://jkpjournal.kalselprov.go.id/index.php/m enu/article/view/78

[8] S. Andarwulan, R. S. Iswati, T. Rihardini, D. T. Anggraini, Penerapan Teknologi Deteksi Dini Stunting Sebagai Upaya Peningkatan Status Gizi Anak Di Kelurahan Siwalankerto Kecamatan Wonocolo Surabaya. Polteknik Dharma Patria, Kebumen, 2020, pp.364-374. https://doi.org/10.37339/jurpikat.v1i3.414

[9] W. Syaroni, Z. Munir, Pemanfaatan Aplikasi Android dalam Mendiagnosa dan Memonitoring Kasus Stuntting Lebih Dini. Sam Ratulangi University, Manado, 2020. pp.189-196. https://doi.org/10.35793/jtek.9.3.2020.30377

[10] Sugiyono, Metode Penelitian Kuantitatif Kualitatif dan R\&D, Alfabeta, 2017

[11] Tegeh $\mathrm{M}$, Jempel $\mathrm{N}$ and Pudjawan $\mathrm{K}$, Model Penelitian Pengembangan, Graha Ilmu, 2014.

[12] M. Iqbal and M. R. Permadi. Going Digital: A New Concept of Indonesian Food Composition Databases. IOP Science, Bristol, 2018, pp. 1-7 . DOI : 10.1088/1755-1315/207/1/012057

[13] M. Iqbal, M. R. Permadi. Analysis of integration dietducate and automated meal planner for nutritional, IOP Science, Bristol, 2020, pp. 1-6. DOI : 10.1088/1755$1315 / 672 / 1 / 012079$ 